\title{
Factors effecting frequency of occurrence of back pain syndromes
}

\section{Jerzy E Kiwerski* \\ The Higher School of Rehabilitation in Warsaw, Poland}

\section{Introduction}

Low back pain syndromes are in the group of the commonest diseases observed in recent years and bear serious medical, social and economic burden. According to European date [1], more than $70 \%$ of population suffered from back pain at least for week in the lifetime, and $15-40 \%$ of population experienced low back pain every year. There is alarming decrease in the age of first onset described by many authors [2]. Peak of morbidity is observed in persons aged between 35 and 55 years, but Japanese study [3] brings evidence that $66,7 \%$ of middle school children has already experienced low back pain lasting for at least 1 week, and relapse rate exceeds $60 \%$. Increase of incidence and morbidity of low back pain is linked to lifestyle alterations including significant limitation of physical activities since young age, changes of hobby preferences, alteration of work habits favouring activities in improper body position lasting for hours or even years, to dynamic physical activity.

The occurrence of such disorders in young people may be understandable when there are significant overloads associated with practising competitive sports [4], but degenerative changes with dehydration of the disc, its destruction $[5,6]$ in young people, not subjected to such overloads, may be astonishing. Adults make extensive use of technological progress, the difference between mental and physical work is blurred. A white-collar worker spends many hours at a desk, a computer, and a manual worker often operates machines also using computer equipment. This leads to prolonged, strenuous static stress, and form relaxation after work do not differ from those preferred by young people: we sit for hours in front of TY-set and computer, continuing under the slogan „rest” overloading of the spine. Remember that sitting position is a form of significant overloud, contributes to more than 2,5 times the pressure in the lower lumbar discs to comparison to standing position, and more than 7 times in comparison to a lying position [7].

Pain may be presented in any phase of spinal overload syndromes. Back pain may result from nociceptive activation in spinal, paraspinal tissues as well as irritating of nervous structures within vertebral canal, when appears as a neuropathic pain. Pain in spondylolisthesis may be related to ligamentous constrain, particularly when posteriori longitudinal ligament (densely supplied with nociceptive endings) is involved.

Commonest back pain syndrome is resulting from long-lasting overload with their typical presentation.

\section{References}

1. Burton AK, Balagué F, Cardon G, Eriksen HR, Henrotin Y, et al. (2006) European guidelines for prevention of low back pain. Eur Spine J 15: 136-168. [Crossref]

2. Balagué F, Troussier B, Salminen JJ (1999) Non specific low back pain in children and adolescents; risk factors. Eur Spine $J$ 8: 429- 438. [Crossref]

3. Sato T, Ito T, Hirano T, Morita O, Kikuchi R, et al. (2008) Low back pain in childhood and adolescence: a cross sectional study in Niigatu City. Eur Spine J 17: 1441-1447. [Crossref]

4. Kujala UM, Kinnunen J, Helenius P, Orava S, Taavitsainen M, et al. (2003) Prolonged low back pain in young athletes: a prospective cause series study on findings and prognosis. Eur Spine J 8: 480-484. [Crossref]

5. Benoist M (2003) Nayural history of aging spine. Eur Spine J 12: 86-89. [Crossref]

6. Dimar JR, Glassman SD, Carreon LY (2007) Juvenile degenerative disc diseases: a report of 76 cases identified by MRI. Eur Spine J 17:323-337. [Crossref]

7. Kiwerski JE (2018) (Edtr). Therapy of lumbar spine pain syndromes. Sci Ed. College of Rehabilitation, Warszaw.
Copyright: (C2019 Kiwerski JE. This is an open-access article distributed under the terms of the Creative Commons Attribution License, which permits unrestricted use, distribution, and reproduction in any medium, provided the original author and source are credited.
${ }^{*}$ Correspondence to: Jerzy E Kiwerski, The Higher School of Rehabilitation in Warsaw, Poland, E-mail: jerzy.kiwerski@wsr.edu.pl

Key words: back pain syndrome, pathogenesis, causes, back pain and lifestyle Received: June 10, 2019; Accepted: June 20, 2019; Published: June 23, 2019 